\title{
A COMPARATIVE STUDY OF \\ BLACK TEA AND INSTANT TEA TO \\ DEVELOP AN INSTANT TEA TABLET \\ WITH RETAINED HEALTH \\ PROMOTING PROPERTIES
}

\begin{abstract}
Bit
PALAMANDADIGE

THARANGI SRIYANGIKA RAJAPAKAKHA MUDALIGE
\end{abstract}

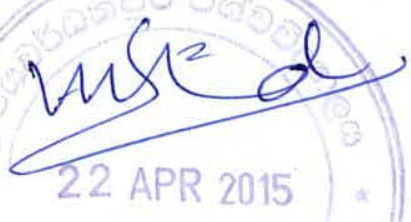

Thesis submitted to the Umiversitty of Sri Jayewardenepura for the award of the Degree of Master of Phillosophy in Pharmacology on December $311^{\mathrm{st}}, 2013$. 


\section{DECLARATION BY CANDIDATE}

"The work described in this thesis was carried out by me under the supervision of Dr. A.K.E. Goonetilleke (Dept. of Pharmacology), Prof. A.M. Abeysekera (Dept. of Chemistry) and Prof. U.G Chandrika (Dept. of Biochemistry) and a report on this has not been submitted in whole or in part to any university or any other institution for another Degree/Diploma”.

Date: $30 \cdot 12 \cdot 13$

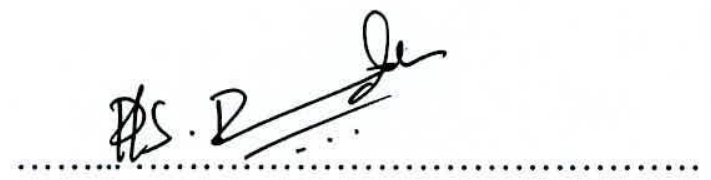

P.T.S.R. Mudalige 


\section{DECLARATION BY THE SUPERVISORS}

"We certify that the above statement made by the candidate is true and that this thesis is suitable for submission to the University for the purpose of evaluation".

Date:.. $30 \cdot 12 \cdot 13$

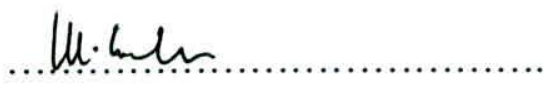

Dr. A.K.E. Goonetilleke

Senior Lecturer in Pharmacology

Department of Pharmacology

Faculty of Medical Sciences

University of Sri Jayewardenepura

Gangodawila, Nugegoda.

Date:...3 $30 \cdot 12 \cdot 13$

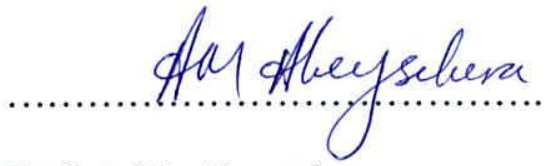

Prof. A.M. Abeysekera

Senior Professor of Chemistry

Department of Chemistry

Faculty of Applied Sciences

University of Sri Jayewardenepura

Gangodawila, Nugegoda.

Date:.......12.13

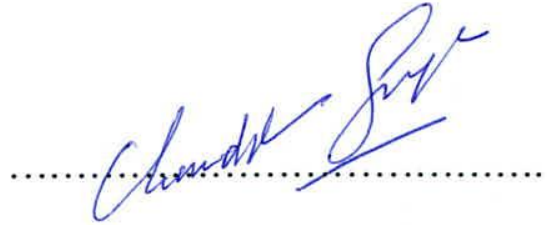

Prof. U.G. Chandrika

Head/Professor

Department of Biochemistry

Faculty of Medical Sciences

University of Sri Jayewardenepura

Gangodawila, Nugegoda. 
We certify that the candidate has made all the required corrections, additions and amendments to the thesis taking into account the comments and suggestions made by the examiners.

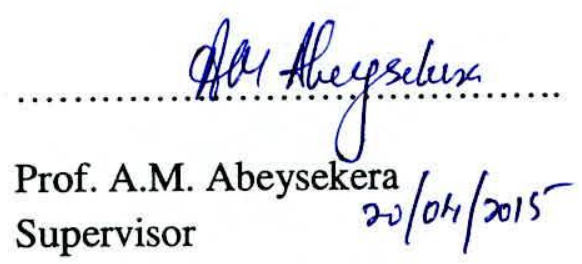

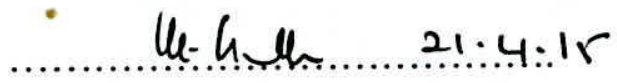

Dr. A.K.E. Goonetilleke

Supervisor

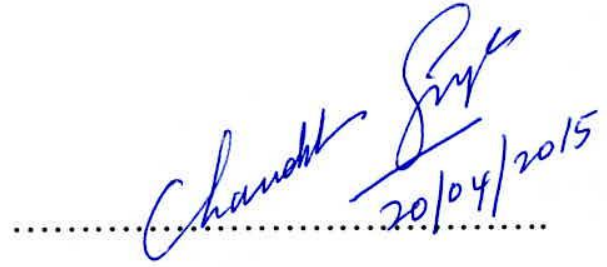

Prof. U.G. Chandrika

Supervisor

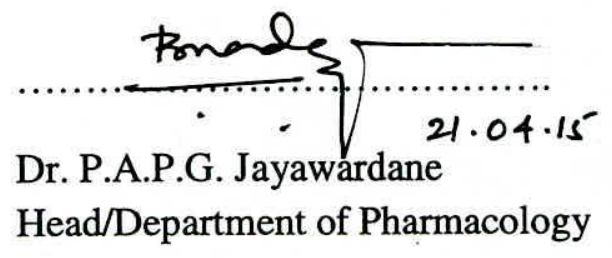

Dr.P. A.P. G. Jayawardane Head, Department ff Pharmacology Faculty of Medical Sciences University of Sri lavewardenepura 
When I am stepping on my way, while finding the success......

\section{My mother... .. My hus6and.....}

Your Love, dedication and devotion towards my needs kept me motivated and inspired even in darkest days.

My dear mother, you are missed with a longing too deep to express.....

I am look forward to the day.....

where we can rejoice together in fieaven.

My Geloved hus6and, sharing our life and love along this journey

is a blessing beyond words...

Your support and constant encouragement...

gave me strength to step further,

while facing to challenges.

In appreciation

for

being part of my life.....

I dedicated my effort

to you. 


\section{TABLE OF CONTENTS}

Page

Table of contents $\quad$ i

List of tables vii

List of figures $x$

$\begin{array}{ll}\text { Abbreviations } & \text { xiii }\end{array}$

$\begin{array}{ll}\text { Acknowledgements } & \text { XV }\end{array}$

Abstract $\quad$ xvii

1. INTRODUCTION AND LITERATURE REVIEW

1.1 General introduction 1

$\begin{array}{ll}\text { 1.2 Introduction to black tea } & 2\end{array}$

1.2.1 The tea plant 2

1.2.2 Black tea 3

1.2.3 Health benefits of tea 6

1.2.4 Chemistry of black tea 9

1.3 Chemical changes during fermentation to produce black tea 11

$\begin{array}{lll}\text { 1.3.1 Theaflavins } & 12\end{array}$

$\begin{array}{lll}\text { 1.3.2 Thearubigins } & 14\end{array}$

$\begin{array}{lll}1.4 & \text { Instant black tea } & 14\end{array}$

1.4.1 Fate of polyphenols during instant tea manufacture $\quad 18$ 
$\begin{array}{lll}\text { 1.5.1 Excipients } & 19\end{array}$

$\begin{array}{lll}\text { 1.5.1.1 Lactose } & 20\end{array}$

$\begin{array}{ll}\text { 1.5.1.2 Mannitol } & 20\end{array}$

1.5.1.3 Microcrystalline cellulose 21

1.5.1.4 Sodium starch glycolate 21

1.5.1.5 Magnesium stearate 22

1.5.1.6 Fumed silica- Aerosil 22

1.5.2 Preparation of formulations 22

$\begin{array}{lll}\text { 1.5.2.1 Moisture absorptivity } & 23\end{array}$

1.5.2.2 Angle of repose 23

1.5.2.3 Compressibility index (CI) 24

$\begin{array}{lll}\text { 1.5.2.4 Moisture content } & 26\end{array}$

1.5.3 The tabletting process 26

1.5.4 Evaluation of tablets 27

$\begin{array}{lll}\text { 1.5.4.1 Hardness } & 27\end{array}$

$\begin{array}{lll}\text { 1.5.4.2 Thickness } & 27\end{array}$

1.5.4.3 Uniformity of weight 28

1.5.4.4 Disintegration time 28

$\begin{array}{lll}\text { 1.5.4.5 Friability } & 29\end{array}$

$\begin{array}{lll}\text { 1.5.5 Stability studies } & 30\end{array}$

1.5.5.1 Real time stability test 30

1.5.5.2 Accelerated stability 30

1.5.6 Microbiological quality 31

$\begin{array}{lll}\text { 1.6 Scope of the thesis } & 31\end{array}$ 


\section{MATERIALS AND METHODS}

2.1 Materials

2.1.1 Solvents

2.1.2 Reagents and standards

2.1.3 Instant tea powder

2.2.2 Sensory evaluation

2.2.3 Studies on polyphenols of brewed and instant tea

2.2.3.1 Total phenols

2.2.3.2 Total flavonoids

2.2.3.3 Theaflavins and thearubigins

2.2.4 HPLC analysis of brewed and instant tea and their theaflavins fractions

2.2.5 Chromatographic analysis of brewed and instant tea and their thearubigins fractions on sephadex $\mathrm{LH}-20$

2.2.6 Determination of antioxidant potential of brewed and instant tea

2.2.6.1 DPPH Free radical scavenging activity

2.2.6.2 ABTS radical cation scavenging activity

2.2.6.3 Ferric reducing ability power (FRAP) assay

2.2.7 Isolation of caffeine from black tea leaves and quantification of caffeine in brewed and instant tea

2.2.8 Studies on the oxidation of phenols in tea brew

2.2.8.1 Oxidation of phenols in tea at different $\mathrm{pH}$ values

2.2.8.2 Oxidation of phenols in tea at different temperatures 56 at $\mathrm{pH}=9.6$ 
2.2.8.3 Oxidation of phenols in tea at different hydrogen peroxide concentrations

2.2.9 In vivo antioxidant assay $\quad 58$

$\begin{array}{lll}2.2 .9 .1 & \text { Assay } & 60\end{array}$

2.2.10 Tabletting 62

2.2.10.1 Preparation of different formulations 62

2.2.10.2 Determination physical properties of formulations 64

$\begin{array}{lll}\text { 2.2.10.3 Preparation of tablets } & 67\end{array}$

2.2.10.4 Determination physical properties of tablets 68

2.2.10.5 Moisture absorptivity $\quad 69$

$\begin{array}{lll}2.2 .10 .6 & \text { Stability studies } & 69\end{array}$

2.2.10.7 Microbiological analysis $\quad 70$

\section{RESULTS AND DISCUSSION}

$\begin{array}{lll}3.1 & \text { Introduction } & 72\end{array}$

3.2 Sensory evaluation of brewed and instant tea 72

3.3 Studies on polyphenols of brewed and instant tea 76

3.3.1 Total phenols and total flavonoids $\quad 76$

3.3.1.1 Total phenols 76

$\begin{array}{lll}\text { 3.3.1.2 Total flavonoids } & 77\end{array}$

$\begin{array}{ll}\text { 3.3.2 Theaflavins and thearubigins } & 78\end{array}$

3.3.3 HPLC analysis of brewed and instant tea and their $\quad 80$ theaflavins fractions

3.3.4 Chromatographic analysis on Sephadex LH-20 84 
3.4 Determination of antioxidant potential of brewed and instant tea 87

3.4.1 DPPH free radical scavenging activity $\quad 87$

3.4.2 ABTS radical cation scavenging activity $\quad 88$

3.4.3 Ferric Reducing Ability Power (FRAP) assay $\quad 89$

3.5 Isolation of caffeine from black tea leaves and 90 quantification of caffeine in brewed and instant tea

3.6 Studies on the oxidation of phenols in tea brew 91

3.6.1 Effect of $\mathrm{pH} \quad 92$

3.6.2 Effect of hydrogen peroxide concentration 93

3.6.3 Effect of temperature 95

3.7 In vivo antioxidant assay 96

3.7.1 TBARS assay for serum and organs 96

$\begin{array}{lll}3.8 & \text { Tabletting } & 98\end{array}$

3.8.1 Preparation of formulations 98

$\begin{array}{ll}\text { 3.8.2 Preparation of tablets } & 101\end{array}$

3.8.3 Physical properties of tea tablets for different formulations 102

$\begin{array}{ll}\text { 3.8.4 Stability tests } & 102\end{array}$

$\begin{array}{ll}\text { 3.8.5 Microbiological analysis } & 105\end{array}$

$\begin{array}{lr}\text { 4. CONCLUSION } & 107\end{array}$

$\begin{array}{ll}\text { 5. REFERENCES } & 108\end{array}$

$\begin{array}{ll}\text { 6. } & \text { APPENDICES } \\ \end{array}$

Appendix 1 - List of Publications $\quad 118$

Appendix 2 - Evaluation Card for Sensory Analysis of Tea brews 119

Appendix 3 - Sample format of sensory evaluation form sent by TRI 120

Appendix 4 - Tea tablet photographs $\quad 121$ 


\section{LIST OF TABLES}

Page

Table 1: Contents of tea polyphenols in tea flush 09

Table 2: $\quad$ Flow properties and corresponding angle of repose 24

Table 3: $\quad$ Flow properties and corresponding compressibility index

Table 4: $\quad$ Average mass of the tablets and corresponding percent deviation by individual tablet mass

Table 5: Absorbance values for tea solutions in Folin-Ciocalteu assay

Table 6: Absorbance values for tea solutions in aluminium chloride colorimetric assay

Table 7: Absorbance values for solutions P, Q and R in the method of Roberts and Smith

Table 8: $\quad$ Average values of absorbance of brewed tea and instant tea

Table 9: Reduction of total phenols in tea during oxidation at different $\mathrm{pH}$ values

Table 10: Reduction of total phenols in tea during oxidation at different temperatures at $\mathrm{pH}=9.6$

Table 11: Reduction of total phenols in tea during oxidation at different hydrogen peroxide concentrations at $60^{\circ} \mathrm{C}$ at $\mathrm{pH}=9.6$

Table 12: Average values of absorbance of brewed and instant tea in TBARS assay

Table 13: Composition of formulations for $500 \mathrm{mg}$ of tablet 
Table 14: Percentage relative humidities of salts used for the test at $20-25^{\circ} \mathrm{C}$

Table 15: Height, diameter and angle of repose of the powder cone in each formulation

Table 16: Bulk volume, tapped volume and compressibility index in each formulation.

Table 17: Estimated median for the variation of sensory characteristic in brewed and instant tea

Table 18: $\quad$ Sensory comparison of brewed tea with instant tea samples

Table 19: Total phenol contents in brewed and instant cups of tea

Table 20: Total flavonoid contents in brewed and instant cups of tea

Table 21: $\quad$ TF and TR contents in brewed and instant cups of tea

Table 22: $\quad \mathrm{IC}_{50}$ values of brewed and instant tea in the $\mathrm{DPPH}^{*}$ scavenging assay

Table 23: $\quad \mathrm{IC}_{50}$ values of brewed, instant tea and trolox in the $\mathrm{ABTS}^{*+}$ scavenging assay

Table 24: Total caffeine contents in brewed and instant cups of tea

Table 25: Initial rates of oxidation of phenols (GAE) in tea at different $\mathrm{pH}$ values

Table 26: Initial Rates of reaction at different peroxide concentrations at $\mathrm{pH}=9.6$ 
Table 27: Effect of temperature on initial rate of reaction

Table 28: In vivo antioxidants effects of brewed and instant tea in the TBARS assay

Table 29: Different physical properties of formulations 99

Table 30: Percentage moisture gain of instant tea powder formulations

Table 31: Physical properties of tea tablets in different formulations

Table 32: Physical properties and antioxidant activity of tea tablets from

formulation $\mathrm{J}$ after storage at ambient temperature and humidity for 12 months at real time

Table 33: $\quad$ Physical properties and antioxidant activity of tea tablets from formulation $\mathrm{J}$ after storage at $60^{\circ} \mathrm{C}$ in an oven for 21 days at accelerated time

Table 34: Effect of light on colour of tea tablets in different storage conditions

Table 35: Microorganisms in different packaging materials with real time (1 year)

Table 36: Microorganisms in different packaging materials with accelerated time (21 days) 


\section{LIST OF FIGURES}

Figure 1: Apical portion of a tea branch showing the tea flush in the encircled region. The polyphenol contents of the different leaves and stem are also indicated

Figure 2: $\quad$ Three major categories of tea

Figure 3: $\quad$ Structures of major flavan-3-ols in tea

Figure 4: Oxidation of flavan-3-ols to theaflavins and thearubigins

Figure 5: $\quad$ Structures of four major types of $\mathrm{TF}$ in black tea

Figure 6: $\quad$ Structure of caffeine

Figure 7: Absorbance vs. concentration of gallic acid

Figure 8: Absorbance vs. concentration of quercetin

Figure 9: $\quad$ Percentage scavenged of DPPH vs. concentration of brewed tea solution

Figure 10: Percentage scavenged of DPPH vs. concentration of instant tea solution

Figure 11: Percentage scavenged of $\mathrm{ABTS}^{*+}$ vs. concentration of trolox

Figure 12: Percentage scavenged of $\operatorname{ABTS}^{*+}$ vs. concentration of brewed tea solution

Figure 13: Percentage scavenged of $\mathrm{ABTS}^{*+}$ vs. concentration of instant tea solution

Figure 14: Standard curve for FRAP assay 
Figure 15: Absorbance vs. concentration of brewed tea solution

Figure 16: Absorbance vs. concentration of instant tea solution

Figure 17: Peak area vs. concentration of caffeine

Figure 18: Experimental set up for measuring angle of repose

Figure 19: HPLC chromatogram of brewed tea

Figure 20: $\quad$ HPLC chromatogram of instant tea

Figure 21: HPLC chromatogram of theaflavin fraction of brewed tea

Figure 22: HPLC chromatogram of theaflavin fraction of instant tea

Figure 23: Sephadex LH-20 chromatogram of brewed tea

Figure 24: Sephadex LH-20 chromatogram of instant tea

Figure 25: Ethyl acetate soluble thearubigins on Sephadex LH-20 chromatogram of brewed tea

Figure 26: Ethyl acetate soluble thearubigins on Sephadex LH-20 chromatogram of instant tea

Figure 27: Oxidation of tea phenols with hydrogen peroxide at different $\mathrm{pH}$ values.

Figure 28: - Log rate vs. - log hydroxyl ion concentration

Figure 29: Oxidation of tea phenols at a hydrogen peroxide concentration of $1.23 \mathrm{~mol} \mathrm{dm}^{-3}$

Figure 30: Oxidation of tea phenols at a hydrogen peroxide concentration of $2.49 \mathrm{~mol} \mathrm{dm}^{-3}$

Figure 31: Oxidation of tea phenols at a hydrogen peroxide concentration of $3.71 \mathrm{~mol} \mathrm{dm}^{-3}$ 


\section{ABBREVIATIONS}

ABTS

CTC

ALU

C

CFU

CSDA

Da

DPPH

DT

EC

ECG epicatechin gallate

EGC epigallocatechin

EGCG epigallocatechin gallate

FCR Folin - Ciocalteu's phenol reagent

GA gallic acid

GAE gallic acid equivalents

GC gallocatechin

GPR general purpose reagent

HPLC high performance liquid chromatography

ISO international standards organization

LLDPE linear low density polyethylene

MCC microcrystalline cellulose

PBS phosphate buffer saline 


$\begin{array}{ll}\text { PET } & \text { polyester } \\ \text { PPO } & \text { polyphenol oxidase } \\ \text { QE } & \text { quercetin } \\ \text { TAMC } & \text { quercetin equivalents } \\ \text { TBA } & \text { 2-thiobarbituric acid } \\ \text { TF } & \text { theaflavins } \\ \text { TF3'G } & \text { theaflavin-3' }{ }^{\prime} \text {-gallate } \\ \text { TF3G } & \text { theaflavin-3-gallate } \\ \text { TFDG } & \text { theaflavin-3,3'-digallate } \\ \text { TLAF } & \text { triple laminated aluminium foil } \\ \text { TPTZ } & \text { 2,4,6-tripyridyl-s-triazine } \\ \text { TR } & \text { thearubigins } \\ \text { TRI } & \text { tea research institute } \\ \text { WHO } & \text { ultra violet - visible } \\ \text { world health organization }\end{array}$




\section{ACKNOWLEDGEMENTS}

\section{I am pleased to express my sincere gratitude.......}

to my supervisors Dr. A.K.E. Goonetilleke - Senior Lecturer of the Dept. of Pharmacology, Prof. A.M. Abeysekera - Senior Professor of Chemistry, and Prof. U.G. Chandrika - Professor in Biochemistry, University of Sri Jayewardenepura, Sri Lanka, for spending their valuable time over my entire project. Their kind and constant advices, encouragement and guidance were a tower of strength for me to bring this venture to a successive completion.

to Dr. (Mrs.) P.A.P.G. Jayawardane - Head, Department of Pharmacology, University of Sri Jayawardenapura who given an invaluable cooperation to expedite the approval process of 'University Grant' for this project.

to, Mrs. Hemanthi Rathnayaka, Mr. Rajitha Manjula Rathnayaka, Mr. Venura Wiroshan Thennakoon, Mr. H.M.Suresh Bandara and Mr.Wasantha Kumara of Formulation, Mrs. Chamari Obesekara - Quality control Department of State Pharmaceutical Manufacturing Corporation for the kind guidance and helping during tabletting process.

to all the Academic and non-academic staff of the departments of Chemistry, Pharmacology, Bio-Chemistry, Food Science, and Mr. Chithraka Wickramarachchi, Department of Statistics, University of Sri Jayawardenapura.

Also, Mr. W.K.Pathirana- Visiting Lecturer in Pharmacy for his enormous guidance given on tableting technology. 
And specially...

to Finlays Tea Estates, Sri Lanka for the financial assistance and,

to University of Sri Jayawardernapura for facilitating a research grant (Grant number ASRIP/06/PR/MED/2011/13) for chemical requirements of the project.

Moreover, to my relations, colleagues of the post graduate research laboratory, department of Chemistry, close friends, my family, for their time, invaluable help, kind cooperation and encouragement during the period of his project and preparation of this theses.

Finally, to my beloved husband for his love, encouragement, guidance, dedication and sincere cooperation, for energizing during hardships throughout this project, to reach for a successful completion. 


\title{
A COMPARATIVE STUDY OF BLACK TEA AND INSTANT TEA TO DEVELOP AN INSTANT TEA TABLET WITH RETAINED HEALTH PROMOTING PROPERTIES
}

\section{Palamandadige}

\section{Tharangi Sriyangika Rajapaksha Mudalige}

\begin{abstract}
The tea plant Camelia sinensis is an evergreen plant which grows under different climatic conditions in Sri Lanka and makes a significant contribution to the economy of Sri Lanka. There is a growing interest in dietary health supplements and tea can be an important source of dietary antioxidants, with its associated health benefits such as reduced risk of cardiovascular disease and cancer. Due to the fast pace of modern life there is a growing interest in ready to drink beverages and instant tea is becoming increasingly popular as a beverage.

The concentration of a hot solution of an industrially produced instant tea powder which is organoleptically equivalent to a standard cup of brewed tea was determined by a thirty member sensory panel. The characteristics chosen were strength, flavour, colour, brightness and overall acceptability. A brewed tea beverage prepared by steeping $1.4 \mathrm{~g}$ of black tea in $140 \mathrm{~mL}$ of freshly boiled water for 3 minutes was found to be organoleptically equivalent to a beverage of instant tea prepared by dissolving $0.21 \mathrm{~g}$ of instant tea in freshly boiled water in the same volume. The total phenols and total flavonoids contents of the equivalent instant and brewed tea beverages were determined
\end{abstract}


using the Folin Ciocalteu assay and the aluminium chloride colorimetric assay respectively. Phenolic content of a cup of instant tea $(704.9 \pm 0.7 \mathrm{mg}$ gallic acid equivalents (GAE)) was much lower than a cup of brewed tea (1090.6 $\pm 3.8 \mathrm{mg} \mathrm{GAE})$. The total flavonoid contents of a cup of instant tea prepared from tea powder $(28.4 \pm 0.8$ $\mathrm{mg}$ quercetin equivalents $(\mathrm{QE}))$ was also much lower than that of a cup of brewed tea $(61.9 \pm 0.4 \mathrm{mg}$ QE). Similarly the theaflavins and thearubigins content determined spectroscopically were found to be lower in instant tea $(1.06$ and $89.32 \mathrm{mg} /$ tea cup respectively) compared to brewed tea ( 89.32 and $322.00 \mathrm{mg} /$ tea cup respectively). The in vitro antioxidant potential of the two tea beverages were determined based on their $\mathrm{IC}_{50}$ values in the scavenging of the 2,2-diphenyl-1-picrylhydrazyl (DPPH) radical, 2,2'azinobis(3-ethylbenzothiazoline-6-sulfonic acid) radical cation and by their ferric reducing antioxidant power (FRAP value). The $\mathrm{IC}_{50}$ values of brewed and instant tea obtained for $\mathrm{ABTS}^{\circ+}$ (6.3 and $17.8 \mu \mathrm{g} / \mathrm{mL}$ respectively) are lower than the $\mathrm{IC}_{50}$ values obtained for DPPH radicals ( $8 \mu \mathrm{g} / \mathrm{mL}$ and $20 \mu \mathrm{g} / \mathrm{mL}$ respectively) but is of the same order of magnitude. FRAP value of brewed tea is also higher than that of instant tea (2100 and $980 \mu \mathrm{M} \mathrm{Fe}(\mathrm{II}) / \mathrm{g}$ respectively). These figures indicate that brewed tea has a higher antioxidant potential than instant tea in vitro. However, the in vivo antioxidant capacity of instant and brewed tea was found to be similar as measured by their effect on the serum and tissues of the heart and lung in mice, at a dose equivalent to twelve cups of tea a day.

The conditions for preparing a hot water soluble tablet from the instant tea powder were optimized. A series of ten formulations were prepared based on the physical properties of moisture absorption, angle of repose, compressibility index and moisture content. The formulation consisting instant tea powder (42\%), anhydrous lactose $(56.3 \%)$, 
microcrystalline cellulose $(1.0 \%)$, aerosol $(0.2 \%)$ and magnesium stearate $(0.5 \%)$ was chosen as the best formulation. Direct compression tablets $(250 \mathrm{mg})$ were made using this formulation to obtain tablets having acceptable values for thickness, hardness, disintegration time, friability and percentage moisture absorption $(5.3 \mathrm{~mm}, 5.0 \mathrm{kPa}, 6$ $\min , 0.14 \%$ and 7.62 respectively).

Real time and accelerated stability studies indicate that the formulated tea tablets are microbiologically stable and retain their antioxidant potential when stored in screw capped amber glass bottles or in triple laminated aluminium foil at room temperature for one year. 